\title{
9.2 コンピュータグラフィックス
}

\section{$9.2 .2,9.2 .3$ 近 藤 邦 雄 ${ }^{* 1}$ (正会員) $9.2 .1,9.2 .4$ 安 生 健 一*2}

本章では, コンピュータグラフィックスの研究動向 として中心的な話題であった SIGGRAPHにおける 論文発表を中心としたアニメーション分野,さらには ノンフォトリアリスティックレンダリング, 自然物の 生成と表現について紹介する。

\subsection{1 アニメーションの発展}

SIGGRAPH 94 は, 1994 年 7 月末に, オーランド にて開催され，SIGGRAPH 95 は，8月にロサンゼ ルスで開催された．本学会は通常 30,000 人程度の参 加者があり, CG 関係者にとっての一大イベントであ るが, 特に昨年は, 史上最高の人出でほぼ 40,000 人 の参加者があった. 1994 年と 1995 年の SIGGRAPH を振り返ると, アニメーションに関する論文がそれぞ れ 10 件以上あり，それまでと比べて，質・量ともに充 実してきている。例えば, 1994 年の論文発表の皮切 りは「ダイナミクス」と銘打たれたアニメーションに 関するセッションであり，しかも，現在最も先進的な テーマのひとつである人工生命 (Artificial Life) に関 する論文 ${ }^{1)}$ から始まった。著者 Karl Sims は超並列コ ンピュータを駆使して新しい映像表現を追求する研究 者・アーティストとして著名であり, 仮想生物の進化 モデルを提案している。この手法によれば，直方体の 塊として表される仮想生物が, 重力の備わった仮想 3 次元空間内を動き, 学習し, 世代交代することで, 自 身の形態にフィットした動きをする．人工生命の手法 に関しては, カナダのトロント大学による, 魚の群れ の自律行動モデルに関する研究があるが, 2 年連続で SIGGRAPHで発表された ${ }^{2) 31}$.これらの論文では, 集団を構成する単体要素の精密な表現, 知覚センサ, 典型的行動パターン化, さらに学習機能までうまく統 合したモデルを提案した。

コンピュータアニメーションによる人物像の表現 は, 相変らず難問の山積する, しかし非常に重要な分

*1 埼玉大学 工学部

*2 株式会社日立製作所

“9. 2 Computer Graphics” by Kunio Kondo (Saitama University, Urawa) and Ken-ichi Anjyo (Hitachi, Ltd., )
野である. 最近はゲームのキャラクタとしてのニーズ 拡大や, 動作の実測技術としてのモーションキャプチ ヤリング手法の高精度化等と同期して, 研究が加速さ れている.人間表現の組織的な研究で世界的に知られ るのはペンシルバニア大学の Norman Badler 教授率 いるグループがある4). 彼らの目標は, 人間工学や生 態学への貢献やそのエンジニアリング応用である. SIGGRAPH 94 では, 人間モデル同士が会話するア ニメーションの自動生成システムを提案している ${ }^{5)}$. しかも会話に伴う表情, 動作, 言葉のイントネーショ ンをルールベースで自動的に生成するものであり, 音 声合成技術等も含めた本格的なシステムである.

SIGGRAPH 95 では, モーションキャプチャで得 られる動作をどのように加工編集すれば，より多様な 動きが生成できるかについての発表があった ${ }^{6) ~ 8)}$. 乇 ーションキャプチャ技術が進歩したといっても，すべ ての動きを事前に実測するのはコスト的にも時間的に も大変であり, また現実離れした誇張された動きこそ しばしば重要である。このような“現場”の問題点に 答えるべく, 実測值のフーリエ変換を用いて動作を内 挿・外挿する方法 ${ }^{6)}$ 等, 簡単だが効果の大きい方法が 提案された。

人間を CG で表すには着衣の表現も重要である。し かし, 動作に伴う布地の変形やしわの表現などをモデ ル化することは難しい問題である。これについては, 人工俳優 (Synthetic Actors) の基礎研究で知られる スイスの Thalmann 教授夫妻の一派が精力的に研究 を続けている ${ }^{910)}$.

モーフィングとは, 簡単にいえば, 2 つの静止画像 を連続的な変化をつけて補間する技術である。その技 術の詳細はともかく, CM や映画での多用によって, 得られる効果はすっかりポピュラーになった感があ る.モーフィング技術のアニメーションへの応用に関 する論文は現在でも, 興味深いものが多い. 例えば, アップル社の論文 ${ }^{11)}$ では，あらかじめ用意されたア ニメーションから動きを抽出し, 別の初期画像を用い て, 抽出された“動き”にもとづく新しいアニメーシ ヨンを自動生成する手法を与えている。一般にモーフ 
イングでは, 変化させる原画像の特徵点の対応付けに 苦慮する。韓国の KAIST では，コンピュータビジョ ンの分野でよく知られたスネークと呼ばれる技術 ${ }^{22}$ を応用してこの問題に挑戦している帛.

以上のほかにも，アニメーションに関する斬新な試 みがいろいろと発表された。時間と位置とを指定され た多関節構造体の動きを, 流行のウエーブレット関数 系を用いて表現する手法 ${ }^{14)}$ や剛体間の摩擦を取り扱

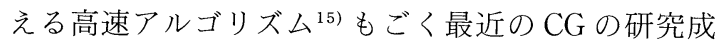
果であり, 問題解決の緒についたばかりである.

(安生)

\section{2 .2 ノンフォトリアリスティック レンダリング}

コンピュータグラフィックス分野では, 1994 年の テレビ年報に示されているように, 高品質のレンダリ ング技術がさかんに研究されてきた。これに対して， この 2 年の間に非写実的表現が注目されるようになっ た。ただし，このような非写実的な表現技術に関する 研究は 90 年代から取り組まれている。このことが広 く知られていない理由は, 写実性の追求という魅力の 影にあまり大きく取り上げられなかったためであろ う。このような中で, SIGGRAPH 94 において発表 されたink and pen を用いた表現技術に関連した報告 が非写実的表現の必要性を見直す機会を与えることと なった。

情報処理学会グラフィックスと CAD の集中研究集 会 ${ }^{16)}$ は, CGの新たなる可能性を求めてノンフォトリ アリスティックレンダリングをテーマとして開催され た。ここで報告された研究を分類すると，ノンフォト リアリスティックレンダリングの研究分野が整理でき る. CG 技術は, 白黒表現, カラー表現, 動画表現, 立体視表現というょうに，表現法を分けることができ る. 非写実的な表現もこれらの分け方をすると, どこ かに分類できる。 また, 利用する分野の違いによって 分類できる。野はテクニカルイラスト, 図面, スケ ッチ, 絵画, 水墨画, 凹版画, 漫画, アニメ, レリー フなどに用いられる表現技術が開発されていることを 示している ${ }^{16)}$ 。この利用分野に従って, この 2 年間で 報告された研究を以下に解説する。

テクニカルイラスト表現を追求した例は, 近藤らに よって報告されている18) 21)。これらは白黒画像によ るイラスト表現を行う手法を提案している. 形状モデ ルがない場合とある場合の両方に利用できる表現手法 である。ドットやラインによるシェーディングや輪郭 線の強調手法を提案している. また, カラー画像によ
る形状理解を助ける手法のために, 隠れ線・隠れ面処 理を同時に行い，線画と面画を合成する手法も提案さ れている。

Winkenbach ${ }^{22223)} ら は$, pen and ink の手法を取り 入れたスケッチ的な表現を提案している. $3 \mathrm{D}$ モデル から自動的にペン画風の画像を生成する手法を提案し ている。テクスチャやエッジを手描き風に表現するこ とができる。テクスチャをすべて均一に表現しないで 一部を省略して表現する方法であり, 明度に応じて描 く線の数を自動的に制御することができる。これに関 連した研究を Eurographics 94 でStrothotteが発表 した。この研究では線の表現と影を線画表現する手法 を用いて, インタラクティブに手書き風の画像を描く システムを構築している．与えられた形状を統一的に 処理するだけでなく，省略すべき部分の領域を与える とその部分に描かれている線が少なくなり，打扔ざっ ぱな感じになる。これによって他の部分が詳しく描か れているようになる。

また, 手描き風で漫画的な画像を描くためには, 線 の表現をさまざまな種類用意する必要がある。このた めの研究として $\mathrm{HSU}^{26)}$ は $2 \mathrm{D}$ ペイントシステムのた めの線表現のためのストロークを用いた画材のシミュ レーションとともに，それを越えた柔軟性が興味深い 点である. 大野 ${ }^{27)}$ は手彫り凹版画の画像生成法を提 案した。画像の濃淡を線の太さや彫り深さ, 間隔など を制御することによって表現できる。

水墨画風の画像生成では, 1991 年の B. Pham の Brush Strokesに関する論文が筆の表現を報告した。 これに関連した研究がいろいろなところで進み，千葉 ら ${ }^{28)}$ は樹木の水墨画表現を報告した。これは墨の移 動・拡散モデルおよび筆と紙のモデル化を試みた点が ユニークなところである. $\mathrm{GuO}^{29)}$ は, 毛筆文字をよ りリアルなものとするためのアルゴリズムを提案して いる.

このような応用の他に, 可視化, つまりビジュラリ ゼーションのための表示技術の研究も行われている. 非写実的な表現は, 以前より可視化分野では行われて いたことである。温度や流れを見せるために各種の表 現法が工夫されてきた。擬似カラー表示や矢印などに よる表示は，レンダリング技術のひとつである，伝え たい情報をうまく伝えるための表現を工夫すること が, これからのコンピュータグラフィックスのひとつ の分野になっていくだろう。例えば，ボリュームデー 夕の表示には計算時間がかかり, リアルタイムの表示 は困難とされていた。このような課題に対して, ボリ ュームデータのプレビューシステムとして斉藤ら ${ }^{30)}$ 
は，対象形状の概略がわかるような表示方法を用いる ことを提案した．対象の概略を示すことを目的とする か, 詳細まで表現するかという，目的に合わせた表示 が必要であることを示している，概略がつかめれば良 い場合に，詳細な表示は必要がないときもある．斉藤 らの研究では, ボクセル值の追跡などをランダムに配 置された空間位置で短い線分の描画に置き換えて，表 示するべき線分の数を制限している。これにより，一 定時間内の応答をスムースにできるようにしている。

また，アニメーションにおけるノンフォトリアリス ティックな表現に関する研究も行われた．金子年は, 次世代アニメーションシステムの構築を目指して， ンフォトリアリスティックアニメーションの生成法を 提案している.これは 3 次元モデルのキャラクタデー 夕を従来の CG のレンダリング手法を用いないで，セ ルアニメタッチの画像を生成することを目標としてい る。単一のシェーディング法をもとに輪郭線を表現し たり、シェーディングを単色にしたりする手法であ る。このようなアニメ画像の表現は，画像の見やすさ だけでなく, 動作の非現実的な誇張がアニメの雾囲気 を生かすことになる。この動作強調の研究は, 佐藤 ら ${ }^{32)}$ が報告している。これはアニメータが動作を表 現するときの規則を分析して, 計算された動きのスピ 一ドや関節の角度変化から速度を誇張したり, キャラ ク夕の大きさを変化させるためのアルゴリズムを提案 している.

以上に示したように，画像を生成する目的や利用は 様々であり, 目的に応じた表現をするために適切な手 法が開発されてきたことがわかる。ノンフィリアリ スティックな表現手法の開発は，写実的表現に対する もうひとつのコンピュータグラフィックスの柱である ことが見直されてきた 2 年といえる.

(近藤)

\section{2 .3 自然物の表現}

本学会のコンピュータグラフィックスの論文特集 ${ }^{40)}$ には, 自然物の表現に関連した研究が 2 編あった。ひ とつは村岡ら ${ }^{33)}$ の積雪の表現である。この積雪表現 は, 積雪現象を分析し, 積雪のシミュレーションモデ ルを提案している.この手法では, 雪粒子という仮想 粒子の行動モデルによる積雪形状を定義している。も

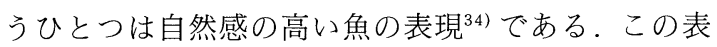
現では, 逆運動学, 協調的運動モデルを利用してお り, 実時間で動く魚の群や魚の形状の変化を実現して いる。

樹木の生成例では, 多頂点の画像を用いて, それら とよく一致するフラクタル形状を生成するアルゴリズ
ム ${ }^{35)}$ が提案されている. 森林景観を表現する手法も 開発された ${ }^{36)}$. この手法では 3 次元幾何モデルから 3 次元テクスチャであるボリュームデー夕を生成し，そ れを山岳地面に配置しレンダリングする。この方法で は遠景の森林景観を表現することができる．

雲の形状の表現手法として, 形状入力表示システム が提案されている ${ }^{37)}$.この研究では雲の空間位置と形 状を指定してインタラクティブに画像を評価すること ができる。さらに, 雲の生成過程を分析して, 時間お よび視点変化を考慮した雲の表現を実現した研究があ る ${ }^{38)}$.これは雲の物理モデルを導入した点に新規性が あり，雲の生成から消滅まで可視化している，陶芸の シミュレーションに関する研究は千葉らのグループ39) が行っている.上薬の発色シミュレーションを行って いる。

自然物の表現は, リアリティを追求するグラフィッ クスのモデリング技術とレンダリング技術の両分野に 関連する領域である。自然物のモデリングが進むと， それを表示する目的も多数となり，レンダリング技術 の開発も一段と増すと考えられる。そのときには, 前 節で述べた非写実的な表現も利用できることになるで あろう。

(近藤)

\section{2 .4 む す び}

最近のSIGGRAPH の論文は，実用に根ざした問 題提起に基づくものが増えている. 従来は, そもそも これこれの表現が CG で可能かどうかといった素朴な 問題意識で始めたものも多かった。例えば自然物のモ デリングでいえばフラクタルによる山の表現などであ る。それはCGの表現能力の誇示ではあったけれど, ぞこにどうやって使うかについての意識はやや希薄で あったかもしれない。しかし，例えばハリウッド映画 を観れば, 自然現象や生物のモデル化の必要性は明ら かであり,ゲームにも 3 次元 $\mathrm{CG}$ キャラクタが登場し より複雑な動作表現が望まれる。さらにインターネッ トの世界におけるエージェントとは何かを構想すると き, $\mathrm{CG}$ の先端技術やディジタル画像処理, 圧縮技術 等を抜きには語れない.

このような期待を背負った分野ではあるが，コンピ ュータグラフィックスとアニメーション分野は, 課題 が山積している若い分野である。人間や生物の動きの 表現にせよ, 剛体の運動にせよ, 現実世界に迫るほど の多様さは，まだ CGの分野では容易に得られないよ うである. 非専門家にとっても，心地良く，また馴染 みやすい対象としての CG 表現が今こそ求められてい る.今後の一層の研究に期待したい.

(安生) 


\section{〔参 考 文 献〕}

1) K. Sima: "Evolving Virtual Creatures", Proc. SIGGRAPH ' 94 pp. 15-22 (1994)

2) X. Tu and D. Terzopouls: "Artificial Fishes: Physics, Locomotion, Perception, Behavior”, Proc. SIGGRAPH’94, pp. 43-50

3) R. Grzeszczuk, et al. : "Automated Laearing of Mustle-Actuated Locomotion Through Control Abstraction”, Proc. SIGGRAPH'95, pp. 63-70

4) N. Badler, et al.: "Simulating Humans", Oxford University Press (1993)

5) J. Cassell, et al.: "Animated Conversation: Rulebased Generation of Facial Expression, Gesture and Spoken Intonation for Multiple Conversation Agents", Proc. SIGGRAPH'94, pp. 413420

6) M. Unuma, et al.: "Fourier Principles for Emotion-based Human Figure Animation”, Proc. SIGGRAPH'95, pp. 91-96

7) A. Bruderlin and L. Williams: "Motion Signal Processing", Proc. SIGGRAPH'95, pp. 97-104

8) A. Witkin and Z. Popovic: "Motion Warping", Proc. SIGGRAPH'95, pp. 105-108

9) P. Volino and N. Magnnat-Thalmann: "Efficient Self-Collision Detection on Smoothly Discretized Surface Animations using Geometrical Shape Regularity", Computer Graphics Forum 13 ( 3 ), pp. 155-166

10) P. Volino, et al.: "Versatile and Efficient Techniques for Simulating Cloth and Other Deformable Objects", Proc. SIGGRAPH'95, pp. 137-144

11) P. Litwinowicz and L. Williams: "Animating Images with Drawings”, Proc. SIGGRAPH'94, pp. 409-412

12) M. Kass, et al. : "Snakes: Active Contour Models", International Journal of Computer Vision, 1, 4, pp. 321-331 (1988)

13) S-Y Lee, et al.: "Image Metamorphosis Using Snakes and Free -Form Deformation", Proc. SIGGRAPH'95, pp. 439-448

14) Z. Liu, et al.: "Hierachical Spacetime Control", Proc. SIGGRAPH'94, pp. 35-42

15) D. Baraff: "Fast Contact Force Computation for Nonpenetrating Rigid Bodies”, Proc. SIGGRAPH'94, pp. 23-34

16）大野: “フォトリアルでない CG 画像表現の手法について”, 情報処 理学会グラフィックスと CAD 集中研究集会, 95, 78 (1995)

17）情報処理学会: “グラフィックスと CAD 集中研究集会研究報告”, 95-CG-76, 95, 78 (1995)

18) Shigehiro Shimaba, Kunio Kondo, Akira Kanbara, Hisashi Sato and Shizuo Shimada : "Interactive Rendering Tool for Technical Illustration", Proceedings of 6th ICECGDG, pp. 762-766 (1994)

19）島田繁広, 近藤邦雄, 佐藤尚, 島田静雄, 神原章 : “ドット・ラインシ エーディングによる白黒画像の強調描画手法”, グラフィックスと CAD シンポジウム (1994)

20）島田繁広, 近藤邦雄, 佐藤尚, 島田静雄, 神原章：“3 次元形状のため の白黑画像の強調描画手法”, Visual Computing'95 (1995)
21）望月義典, 近藤邦雄, 佐藤尚, 島田静雄：“形状理解を容易にする特 徵強調画像の生成”, 情報処理学会研究報告, 95, 78, pp. 73-80 (1995)

22) Michael P. Salisbury, Sean E. Anderson, Ronen Barzel, and David H. Salesin: "Interactive Pen-and-Ink Illustration", Proceedings of SIGGRAPH'94 (Orlando, Florida, July 24-29, 1994), In Computer Graphics, Annual Conference Series (1994)

23) Georges Winkenbach, David H. Salesin: "Computer Generated Pen-and-Ink Illustration”, Proceedings of SIGGRAPH'94 (Orlando, Florida, July 24-29, 1994), In Computer Graphics, Annual Conference Series (1994)

24) T. Strothtte, B. Preim, A. Raab, J. Schumann, D. Forsey: "How to Render Frames and Influence People", Proceedings of Eurographics94 (1994)

25) X. Li, D. Juricic: CAD Produced "Personalized Freehand Sketching", Proceedings of 6th ICECGDG, pp. 757-761 (1994)

26) Siu Chi Hsu, Irene H. H. Lee: "Drawing and Animation Using Skeletal Strokes", Proceedings of SIGGRAPH'94 (Orlando, Florida, July 24-29, 1994), In Computer Graphics, Annual Conference Series (1994)

27) T. Shirouzu, Y. Ohno: "Computer-Aided Plate Making for Intaglio Printing", Proceedings of 6th ICECGDG, pp. 708-712 (1994)

28）張青, 高橋淳也ほか: “樹木の水墨画調レンダリング”, 情報処理学 会グラフィックスと CAD 集中研究集会, 95, 78 (1995)

29) O. Guo: “An integration of font and CG techniques”, 情報処理学 会グラフィックスと CAD 集中研究集会, 95, 78 (1995)

30）斎藤隆文：“Comprehensible Rendering一これからの課題”, 情報処 理学会グラフィックスと CAD 集中研究集会, 95, 78 (1995)

31）金子, 中嶋：“ノンフォトリアリスティックアニメーションの生成”, 情報処理学会グラフィックスと CAD 集中研究集会, 95, 78 (1995)

32）佐藤, 近藤ほか：“アニメーション制作に㧍けるキャラク夕の動作 強調 Motion Filter”, テレビ誌, 49, 10 (1995)

33）村岡, 千葉, 太田：“冬期の近接景観のシミュレーションのための積 雪モデル”, テレビ誌, 49, 10 (1995)

34）河村, 土肥, 石塚：“NURBS, 逆運動学, 協調的運動モデルによる自 然感の高い魚の実時間動画像生成”, テレビ誌, 49, 10 (1995)

35）桑原, 志和, 岸野: “多視点樹木を入力するフラクタルモデルを用い た 3 次元樹木形状自動再構成法”, 画電学会, Visual Computing'95 (1995)

36）土井ほか：“3 次元テクスチャによる森林景観のビジュアルシミュ レーション”, 画電学会, Visual Computing Workshop'95 (1995)

37）多田村, 大原, 中前：“雲の形状入力表示プログラムの開発”, 画電学 会, Visual Computing'95 (1995)

38）倉立：“時問および視点変化を考慮した雲の可視化”, 画電学会, Visual Computing Workshop'95 (1995)

39）川瀬, 西岡, 千葉：“陶芸のCG に向けた基礎的研究”, 情報処理学会 グラフィックスと CAD シンポジウム論文集 (1995)

40）論文特集号“最先端画像映像生成処理技法”，テレビ誌， 49, 10 (1995) 